\title{
Efficient Market Hypotheses Controversy and Nigerian Stock Exchange Relations
}

\author{
Ejem Chukwu Agwu', Ogbonna Udochukwu Godfrey ${ }^{2}$, Okpara Godwin Chigozie ${ }^{3}$ \\ ${ }^{1}$ Department of Banking and Finance, Abia State University, Uturu, Nigeria \\ ${ }^{2}$ Department of Management Science, Rhema University, Aba, Nigeria \\ ${ }^{3}$ Department of Banking and Finance, Abia State University, Uturu, Nigeria
}

Email address:

ecjah71@yahoo.com (E. C. Agwu)

\section{To cite this article:}

Ejem Chukwu Agwu, Ogbonna Udochukwu Godfrey, Okpara Godwin Chigozie. Efficient Market Hypotheses Controversy and Nigerian Stock Exchange Relations. International Journal of Accounting, Finance and Risk Management. Vol. 5, No. 3, 2020, pp. 131-140. doi: $10.11648 /$ j.ijafrm.20200503.12

Received: May 25, 2020; Accepted: June 8, 2020; Published: June 28, 2020

\begin{abstract}
The endless arguments on which Efficient Market Hypotheses form Nigeria Stock exchange (NSE) belongs incited this study; Efficient Market Hypotheses controversy and Nigerian Stock Exchange Relations. In order to achieve the aim of this study, the All Share Index (ASI) with daily data from January 02, 2014 to May 20, 2019 (1333 observations) and annual data from 1985 to 2018 (34 observations) collected from the Nigeria Stock Market fact books. The study employed three analytical methods namely the unit root test, GARCH Model and the Autocorrelation cum patial autocorrelation method for the assessment of weak form hypothesis on the daily and annual all share index in the Nigerian Stock market. The results of these evaluations indicated a significant relationship between the price series and their lagged values implying that stock price series do not follow a random walk process in Nigerian stock market. Thus, affirming that the Nigeria Stock Exchange is not efficient in weak form. In the light of this, the researchers recommend that the supervisory and regulatory authorities should strengthen the Nigerian Stock Market through palliating its regulations pertaining to transparency of information management rules such as market barriers and stringent listing requirement, publication of accounts, notices of annual general meeting and the like.
\end{abstract}

Keywords: Random Walk, Capital Market Efficiency, Unit Root Test, GARCH Model, Autocorrelation

\section{Background of the Study}

An indispensable concept underlying investment analysis is the imagination of efficient stock market. From economic perspective, the efficiency of stock markets is the key to optimal allocation of resources. On the investor's dimension, it is necessary to have an efficient stock market to ensure that the investor is involved in a fair game. However, the efficient market hypothesis (EMH) was developed from the Random Walk Theory. The EMH says that the market is efficient at all times implying that share price instantly reflect available information in the market. For that the market is efficient when the market price is only good and correct guide for the share selection. It can also mean that all known information is immediately discounted by all investors and reflected in share prices in the stock market. As such, no one has information edge to make abnormal profit. In the ideal efficient market, every investor knows all available information simultaneously, interprets it similarly, and believes rationally $[16,13,34,23,10]$. The rationale of the Efficient Market hypothesis (EMH) is that stock markets do not operate in a vacuum, its environment is dynamic and the future is always full of uncertainties. Thus, once the intrinsic value of a share is determined at issue and the price ascertained, future prices will level up to the new information, which itself is fully unpredictable. It was probably in recognition of this fact that Fama [24] argued that in a situation where successive bits of new information arise independently across time and investors' conceptions are inconsistent, successive price changes would be independent. Put differently, Stock prices appear to follow a random walk, hence the term random walk hypothesis. Similarly, Samuels and Wilkes [60] defined an efficient 
market as one in which prices of traded securities always fully reflect all publicly available information concerning those securities. Furthermore, Samuels and Wilkes [60] identified necessary conditions for an efficient market to include accurate signals for investors' choices. This implies that today's price which reflects all publicly available information is the best estimate of tomorrow's price [50].

This concept of efficient stock markets stemmed for a chance discovery. In 1958 Maurice Kendall, a British statistician, presented a controversial paper to the Royal Statistical Society on the behavior of stock and commodity prices. Kendall had expected to find regular price cycles, but to his surprise they did not seem to exist. Each series appeared to be a wandering one, almost as if once a week the Demon of Chance drew a random number... and added it to be current price to determine the next week's price. In other words, the price and commodities seemed to follow a random walk of stocks [12]. This means that market efficiency is consistent with a market in which there are no transactions costs in trading securities; all available information is costless to all market participants, and all participants in the market are rational in decision, suggesting that all agree on the implications of current information for the current price and distributions of future prices of each security [26]. Rossi and Gunardi [58] contend that the stock market is an important principle used to measure the efficiency as the correlation between prices and all the information present in a market. Reily [55] sees an efficient market as one in which security prices adjust rapidly to the infusion of new information and current stock prices fully reflect all available information, including the risks involved. Thus, a stock market is said to be efficient if information is widely and cheaply available to investors such that share prices are fair. A fair share price is one which reflects all available, relevant, and ascertainable information in the market. The efficient market hypothesis may be expressed in a number of alternative ways, and differences between these alternative representations can easily become rather esoteric, technical and subtle [16]. The implication is that security prices adjust instantly and without bias to any new information released to the market and that expected return is compatible with the risk involved [4]. An Efficient Stock market results from the presence of numerous, rational profit maximizing investors, who are actively competing with one another and these resulted to three variants of efficient market hypothesis (weak, semi-strong and strong forms [65, 18, 63, 33, 35].

In the words of Downey and Scott [19], the efficient market hypothesis (EMH), alternatively known as the efficient market theory, is a hypothesis that states that share prices reflect all information and consistent alpha generation is impossible. According to the EMH, stocks always trade at their fair value on exchanges, making it impossible for investors to purchase undervalued stocks or sell stocks for inflated prices. Therefore, it should be impossible to outperform the overall market through expert stock selection or market timing that is a type of investment or trading strategy. It is the act of moving in and out of a financial market or switching between asset classes based on predictive methods [61] and the only way an investor can obtain higher returns is by purchasing riskier investments. Okpara [46] believed in reality, the appraised values of a security are based on the assessment made by independent investors. While the assessment made by independent investors dependent on the background and information available to him. Financial information is the building blocks from which the analysts construct research analysis that form the bases for their investment recommendations. In such a market, the current price of a security obviously "fully reflects" all available information. But the speed and manner in which the market adjusts to the relevant information on dividend and bonus issues declaration has been punctuated by untimely release of information and poor behavior of the authorities. The excruciating influence of timidity that could emanate from insecurity of investors due to the intending insider trading and fall in investors' confidence, deters trading activities and the performance of the market [40]. In information efficient market, prices of shares adjusts quickly to new information and enable more informed and efficient investment choices [51]. In such markets, investors do not care about various trading strategies by fundamentalists, technicalist or chartists to beat the market with the bid of earning abnormal returns. But in the Nigeria capital market, the case is the reverse. In most cases, investors pay extra money to acquire additional information and sometimes go as far as sourcing for insider information on the values of companies listed with the exchange. So far, before certain information is announced, some investors have already traded on the information, causing disparities in available information among market participants.

These discrepancies in the information available to equity issuers or investors could results to overpricing or under pricing of shares [29, 7]. When a share is overpriced or underpriced as a result of insider information, the level of confidence in the market would be deterred and the returns of the firms would be affected. In turn, the contributions of the firms to all share indexes and the market capitalization would be insignificant. This is because, Investors who are always risk averse could withdraw their money or invest it in other less productive ventures, leaving the market performance gauges in a shamble state $[28,4,30]$. Stock prices change so that after an adjustment to reflect information like dividends, bonuses, merger and acquisition, earning etc, the time value of money and differential risk equal the market's best forecast of the future price. Therefore, the only factors that can change stock prices are random factors that could not be known in advance [62].

On the relationship between stock market and efficient market hypothesis, Okpara [44] found that the market follows a random walk but further investigation of the reforms shows that the market was inefficient during the financial deregulation, privatilisation and the internationalization of the capital market while the year 2000 to 2006 recorded persistent volatility clustering suggesting weak form inefficiency. Thus, beside these years, the finding 
suggests that other years were conspicuously and significantly found to exhibit weak form efficiency. $\mathrm{He}$ therefore concluded that the Nigerian capital market is weak form efficient. In addition, other studies such as Udoka [64], Bashir et. al [8], also supported Okpara [44, 45] that shows weak form efficiency of the Nigerian capital market even though different models and data set were employed in their analysis. Most of the empirical studies reviewed follow a random walk, suggesting the independence of successive price changes of share prices in the market. This implies that investors cannot consistently outperform the market using past information on share prices. This does not mark the end of further enquiry on weak form efficient market hypothesis and Nigerian capital market. Studies by Emenike [22] and Agwuegbo et. al [5] refuted prepositions of random walk hypothesis. Their study is consistent with the findings of Sabur and Vitali, [59].

The researchers in this study are bordered with endless arguments on which EMH form Nigeria Stock exchange (NSE) belongs. Most arguments have concluded that NSE is weak form efficient while others are against it. Again most of the empirical studies made use of daily, weekly, monthly, quarterly data or combination of them to arrive at their conclusion. Therefore, researchers here are anxious to take an empirical stand by examining the controversy between the Nigeria Stock Exchange and weak form EMH with annual data and daily data.

The other sections of this study are structured as follows. Section 2 reviews theoretical and empirical literature related to this study, section 3 describes the data and methods, section 4 analyzes and discusses the findings of this study, and finally section 5 concludes and recommends for policy making.

\section{Literature Review}

In this section, theoretical and empirical literatures will be reviewed. Firstly the theoretical literature review will be discussed before discussing the empirical literature.

\subsection{Theoretical Literature Review}

The random walk hypothesis was first formalized by a French mathematician Bachelier [8] who presented convincing evidence that commodity speculation in France was a "fair game" meaning that neither buyers nor sellers could expect to make profit [47]. The induction for random walk hypothesis is a variation on the economists classical efficiency argument which holds that $\$ 100$ bill will never be found lying on the sidewalk because someone else would have packed it up first. This intuition incited study on the issue and for the past century it has been exhaustively debated upon.

Pearson [53] become perplexed by the problem of the random walk and after making some analytical observations appealed to the readers of nature for a solution as the problem was of considerable interest to him. The random walk also known as the drunkards walk is central to probability theory and still occupies the quantitative mind today.

Rayleigh [54] responded to the appeal of Pearson and his contributions led Pearson to conclude that "the most probable place to find a drunkard who is at all capable of keeping on his feet is somewhere near his starting point. Applying the random walk theory to finance and precisely stock market, it is contended that stock prices take a random and unpredictable path. The chance of a stock future price going up is the same as its going down implying that stock prices change randomly, thus making it impossible to be predicted.

In the words of Fama [24] successive price changes in individual securities are independent depicting that the past history of the series cannot be used to predict the future in any meaningful way. Fama [26] categorized three types of efficient markets as weak-form, semi-strong and strong form efficiency. The least form covers all past information concerning prices and returns; the semi-strong form covers all publicly available information while the strong form covers all information be it private and public. The strong form of the efficient market hypothesis states that current market price instantaneously and fully reflects all pertinent information including everything that is known whether it is public or private so that no group of investors has a monopolistic access to any information that could be usurped to beat the market.

Malkiel [39] a Princeton university Professor of Economics through his book, "a random walk down wall street" popularized the random walk hypothesis using a hypothetical stock whose closing price was determined by a conflict. Thus the random walk theory is based on the occurrence of an unpredictable event determined by a series of random event. [47]. The three categories of efficient market were upheld and could be discussed in details as follows:

\subsubsection{Weak Form and Random Walk EMH}

This is the oldest statement of the hypothesis. It holds that present stock market prices reflect all known information with respect to past stock prices, trends and volumes. The weak form of the EMH is summed up in the words of the pseudonymous 'Adam Smith', author of the Money Came: 'Prices have no memory, and yesterday has nothing to do with tomorrow' [10, 12, 13]. A capital market is said to be weakly efficient or satisfy weak form efficiency if it fully incorporates the information in the past stock prices. Thus the preceding strategy would not be able to generate profit if weak form efficiency holds [56]. Most times weak form efficiency is represented mathematically as:

$$
P_{t}=P_{t-1}+\text { Expected Return }+ \text { Random Error }
$$

The above equation can be interpreted as; price today is equal to the sum of the past last observed price plus the expected return on the stock (Naira) plus a random component occurring over the interval. The last observed price could have happened yesterday, last week, or last month, depending on the sampling interval. However, Ross, 
Westerfield, Jaffe and Jordan [56] observed that weak form efficiency is about the weakest type of efficiency that we would expect a financial market to display because historical price information is the easiest kind of information about a stock to acquire.

\subsubsection{Semi-strong form EMH}

This hypothesis states that all publicly available information regarding the prospects of a firm must be reflected already in the stock price. Such information includes, in addition to the past price, fundamental data on the firm's product line, quality of management, statement of financial position, patent held, earning forecast and accounting practices. Again, if investors have access to such information from publicly available sources, one would expect it to be reflected in stock prices [11]. A market is semi strong efficient if prices reflect (incorporate) all publicly available information, including information such as published accounting statement for firm as well as historical price information $[12,13,56]$.

\subsubsection{Strong form EMH}

A market is strong form efficient if prices reflect all information, private or public [12, 13, 56]. This version of EMH states that stock prices reflect all information relevant to the firm, even including information available only to company insiders. This variant of the hypothesis is quite extreme. Few would argue with the proposition that corporate officers have access to pertinent information [11, 12]. It concerned with whether or not certain individuals or group of individuals possess inside information which can be used to make average profit. If the strong form of the efficient capital market hypolthesis holds, then any day is as good as any other day to buy any stock $[10,13]$.

\subsection{Empirical Literature}

The efficiency stance of the Nigerian stock market has in the past and presently led to unending controversy. As such has resulted to plethora of empirical studies on the efficient markets hypothesis globally and Nigeria in particular. Some empirical literature reviewed reveal that actually that past share prices cannot be used as a predicting factor to ascertain future share prices movement in Nigerian stock market, indicating that successive price changes in the market follow a random walk [6, 9, 21, 43, 48, 64]. Efforts will be geared to examine some empirical literature to aid the researchers to have a better position on the subject matter. However, applying correlation analysis and monthly stock returns data over the period January 1981 and December 1992, Olowe [48], studied weak form efficiency of the Nigerian stock market to examine if share prices on the Nigerian stock market adjust to historical price information. The study research revealed that the Nigerian market is efficient in weak form.

Employing GARCH and time-varying parameters, to test evolving efficiency for early periods of 1990s and ending of June 2001, Keith and Graham [36] examined the efficiency of seven African stock markets such as; South Africa, Egypt, morocco, Nigeria, Zimbabwe, Mauritius and Kenya. The test of evolving efficiency found that the Johannesburg stock market was weak form efficient throughout the period under study while Egypt and morocco stock markets tested weak efficient from 1999. Also their findings show that Nigerian market was weak form efficient from early 2001 suggesting that the market follow a random walk. In addition, their result further indicated that Kenya and Zimbabwe stock markets show no tendency towards weak form efficiency, whereas Mauritius market displays a slow tendency to eliminate inefficiency.

With Cointegration and Granger causality tests Augmented Dickey Fuller (ADF-1979, 1981), Phillips-Perron (PP-1988), Dicky-Fuller Generalized Least Square (DF-GLS-1996) and Elliot-Rothenberg-Stock (ERS - 1996) tests, Cooray and Wickramasighe [15] investigated weak and semi strong form of the efficiency in four South Asian stock markets such as India, Sri Lanka, Pakistan and Bangladesh. After the analysis, Semi-strong form efficiency was not supported as their tests indicate a high degree of interdependence among the South Asian stock markets

Chien-Chong, Jung-De and Chi-Chuan [14] employed a state-of-the-art panel data stationarity test which incorporates multiple structural breaks to whether the efficient market hypothesis holds in stock markets under different economic development levels using January 1999 to May 2007. After the empirical analysis, it was observed that using general forms of cross-sectional dependence as well as controlling for finite-sample bias, the real stock price series appear to be stationary in 32 developed and 26 developing countries. Again,, real stock price indices are stationary processes that are inconsistent with the efficient market hypothesis.

Ajao and Osayuwu [6] engaged serial correlation technique and runs test to examine the weak form of efficient market hypothesis in the Nigerian capital market. The study covered all securities traded on the floor of the Nigerian Stock Exchange and the month end value of the All Share Index from $2001-2010$. The serial correlation technique of data analysis was used to test for independence of successive price movement and the distributive pattern while runs test was used to test for randomness of share price movement. The result of the serial correlation found that the correlation coefficients did not violate the two- standard error test. Again, the Box-Ljung statistic revealed that none of the serial correlation coefficients was significant and the Box pierce Qstatistics indicated that the overall significance of the serial correlation test was poor while the result of the distribution pattern shows that stock price movements are approximately normal. On the basis of this finding, they conclude that successive price changes of stocks traded on the floor of the Nigerian Capital Market are independent and random therefore, the Nigerian Capital Market is efficient in the weak-form.

Applying run test and the correlegram/partial autocorrelation function as alternate forms of the research instrument, Okpara [44] investigated stock market prices and 
the random walk hypothesis. The results of the three alternate tests revealed that the Nigerian stock market is efficient in the weak form and therefore follows a random walk process.

Also Okpara [44] employed GARCH model to further examine the weak form test of the market during the periods of financial deregulation in 1987, public companies privatization in 1988 and internationalization of the Nigerian capital market. The results revealed that the market follows a random walk but further investigation of the reforms showed that the market was inefficient during the financial deregulation, privatization and the internationalization of the capital market while the year 2000 to 2006 recorded persistent volatility clustering suggesting weak form inefficiency. The balanced results suggested that other years were conspicuously and significantly found to exhibit weak form efficiency.

Sabur and Vitali [59] investigated weak-form efficiency in Africa via multi-approach; unit root, auto-correlation, runs and variance ratio tests on the daily price indices of Egypt, Kenya, Mauritius, Morocco, Nigeria, South Africa and Tunisia over the period 1999-2009. The result obtained indicated the rejection of the random walk hypothesis for all stock markets indices over the whole sample period except South Africa market.

With non-parametric runs test, Afego [4] x-rayed the weak-form efficient markets hypothesis for the Nigerian stock market by examining the random walks in the monthly index returns over the period 1984-2009. The results found that index returns on the Nigerian Stock Exchange (NSE) display a predictable component, indicating that traders can earn superior returns by employing trading rules. The statistically significant deviations from randomness are also suggestive of sub-optimal allocation of investment capital within the economy. The findings, in general, contradict the weak-form of the efficient markets hypothesis.

Gimba [31] examined the weak form EMH of the NSE using daily and weekly NSE All Share Index (ASI) and five most traded banks stock of NSE from January 2007 to December, 2009 for the daily and from June 2005 to 2009 for the weekly data. The results revealed that autocorrelation test affirm weak form is inefficient.

Goudarzi [32] used ADF test and GARCH model to examine market efficiency in India Stock Market through modeling one asset return series. The outputs indicated that underlying series is stationary, mean reverting. Therefore, based on the results the study concluded that the Indian stock market is weak form inefficient.

Employing seven (7) parametric tools; Autocorrelation test, the ADF and P-P unit root tests, Variance Ratio test, the Normality/Random test, the Granger Causality test ARCHGARCH test and Regression test, Ogbulu [42] investigated the efficiency level of Nigerian Stock Exchange (NSE) across different data estimation intervals (daily, weekly, monthly and quarterly aggregate stock price data using the NSE all share index series from 1999 to 2013) with reference to the weak form variant of EMH. The result found that on balance the NSE is weak form inefficient when daily, weekly, monthly and quarterly prices are examined irrespective of the estimation interval and the parametric test employed in the tests.

Adebanjo, Awonusi and Eseyin [1] looked at the weak- form efficiency of the Nigerian stock market. Employing Partial autocorrelation (PACF) test to test for independence of stock prices, the runs test and the distribution patterns to test for randomness of stock prices and the one-sample Kolmogorov Smirnov test to examine the observable trend in the pattern of stock price movements. After the analysis, the movements of stock prices in the stock market were observed to be independent. The movements of stock prices in the stock market were not random. Also was an observable trend in the pattern of stock prices movement in the stock market. The result of the partial auto correlation test showed that the movements of the stock prices are independent. Again the result of the runs test and the distribution patterns also shows that the movements of stock prices were not completely random.

\section{Data and Tools}

This study employed Unit root test, GARCH Model and the Autocorrelation cum patial autocorrelation methods to settle controversy on Efficient Market Hypothesis (EMH) and Nigerian Stock Market. This is in accordance with Fama's precondition, which suggested that a market cannot be semi strong form efficient if not efficient in its weak form first, hence studies in and outside Nigeria have followed suit to examine if current share prices fully reflect publicly available information, such that, investors cannot seize any privileged information as an advantage to outperform the market [26, 49, 2, 14, 3, 52, 32]. The study employed two intervals of All Share Index (ASI) with daily data from January 02, 2014 to May 20, 2019 (1333 observations) and annual data from 1985 to 2018 (34 observations) collected from the Nigeria Stock Market fact books.

\section{Results and Interpretations}

This study commenced with examining the distribution of daily and annual data with descriptive statistics shown below;

\subsection{Descriptive Statistics}

Table 1. Descriptive Statistics.

\begin{tabular}{lll}
\hline & DAILY_ASI & ANNUAL_ASI \\
\hline Mean & 32982.60 & 15205.32 \\
Median & 32203.62 & 11550.40 \\
Maximum & 45092.83 & 45908.88 \\
Minimum & 22456.32 & 127.3000 \\
Std. Dev. & 5642.280 & 13992.35 \\
Skewness & 0.250139 & 0.594573 \\
Kurtosis & 1.872985 & 2.254315 \\
Jarque-Bera & 84.44774 & 2.790994 \\
Probability & 0.000000 & 0.247710 \\
Sum & 43965802 & 516980.8 \\
Sum Sq. Dev. & $4.24 \mathrm{E}+10$ & $6.46 \mathrm{E}+09$ \\
Observations & 1333 & 34 \\
\hline
\end{tabular}

Authors' computation output using E-view 10. 
Table 1 above summarized the distribution of daily and annual all share index (ASI). The table revealed that daily data Jarque Bera recorded coefficient of 84.44774 with probability value of 0.000000 suggesting an abnormal distribution, while annual data Jarque Bera has coefficient of 2.790994 with probability value of 0.247710 indicating a normal distribution. Next is unit root test, which in macroeconomic analysis is a popular test of stationarity of time series data; because of the dependent nature of most economic variables. This study use ADF unit root as shown below;

\subsection{Unit Root Test}

Table 2. Unit root at Level.

\begin{tabular}{|c|c|c|c|}
\hline \multicolumn{4}{|c|}{ Null Hypothesis: DAILY_ASI has a unit root } \\
\hline \multicolumn{4}{|c|}{ sExogenous: Constant } \\
\hline \multicolumn{4}{|c|}{ Lag Length: 1 (Automatic - based on SIC, maxlag=22) } \\
\hline & & t-Statistic & Prob.* \\
\hline \multicolumn{2}{|c|}{ Augmented Dickey-Fuller test statistic } & -1.817730 & 0.3721 \\
\hline \multirow[t]{3}{*}{ Test critical values: } & $1 \%$ level & -3.435052 & \\
\hline & $5 \%$ level & -2.863504 & \\
\hline & $10 \%$ level & -2.567865 & \\
\hline \multicolumn{4}{|c|}{ Null Hypothesis: ANNUAL_ASI has a unit root } \\
\hline \multicolumn{4}{|c|}{ Exogenous: Constant } \\
\hline \multicolumn{4}{|c|}{ Lag Length: 0 (Automatic - based on SIC, maxlag $=8$ ) } \\
\hline \multicolumn{2}{|c|}{ Augmented Dickey-Fuller test statistic } & -1.235789 & 0.6469 \\
\hline \multirow[t]{3}{*}{ Test critical values: } & $1 \%$ level & -3.646342 & \\
\hline & $5 \%$ level & -2.954021 & \\
\hline & $10 \%$ level & -2.615817 & \\
\hline
\end{tabular}

Table 3. Unit at $1^{s t}$ Difference.

\begin{tabular}{|c|c|c|c|}
\hline \multicolumn{4}{|c|}{ Null Hypothesis: D (DAILY_ASI) has a unit root } \\
\hline \multicolumn{4}{|c|}{ Exogenous: Constant } \\
\hline \multicolumn{4}{|c|}{ Lag Length: 0 (Automatic - based on SIC, maxlag=22) } \\
\hline & & t-Statistic & Prob.* \\
\hline \multicolumn{2}{|c|}{ Augmented Dickey-Fuller test statistic } & -30.12417 & 0.0000 \\
\hline \multirow[t]{3}{*}{ Test critical values: } & $1 \%$ level & -3.435052 & \\
\hline & $5 \%$ level & -2.863504 & \\
\hline & $10 \%$ level & -2.567865 & \\
\hline \multicolumn{4}{|c|}{ Null Hypothesis: D (ANNUAL_ASI) has a unit root } \\
\hline \multicolumn{4}{|c|}{ Exogenous: Constant } \\
\hline \multicolumn{4}{|c|}{ Lag Length: 1 (Automatic - based on SIC, maxlag $=8$ ) } \\
\hline \multicolumn{2}{|c|}{ Augmented Dickey-Fuller test statistic } & -5.970826 & 0.0000 \\
\hline Test critical values: & $1 \%$ level & -3.661661 & \\
\hline & $5 \%$ level & -2.960411 & \\
\hline & $10 \%$ level & -2.619160 & \\
\hline
\end{tabular}

Authors' computation output using E-view 10.

Tables 2 and 3 depict the results of unit test for daily ASI and annual ASI. The results revealed that both daily and annual data are not stationary at level, rather are both differenced once to be stationary at $5 \%$. Since their level series are not stationary but can be differenced of order one to be stationary, the researchers conclude that the price movements in the Nigerian stock exchange exhibit no random walk phenomenon. In other words, the Nigerian Stock Market is not weak form efficient. However, researchers such as Liu and $\mathrm{He}$ [38] argued that the unit root tests may not detect departures from a random work; one has to be cautious of this result. In view of this, the researchers resorted to using the GARCH Model as well as Autocorrelation and partial Autocorrelation tests to verify the authenticity of the result.

\subsection{GARCH Test}

The result of the GARCH model is presented in tables 4 and 5 as follows.

Table 4. GARCH Test.

\begin{tabular}{|c|c|c|c|c|}
\hline \multicolumn{5}{|c|}{ Dependent Variable: DAILY_ASI } \\
\hline \multicolumn{5}{|c|}{ Method: ML ARCH - Normal distribution (BFGS / Marquardt steps) } \\
\hline \multicolumn{5}{|c|}{ GARCH $=$ C (3) + C (4)*RESID $(-1)^{\wedge} 2+C(5)^{*}$ GARCH (-1) } \\
\hline Variable & Coefficient & Std. Error & z-Statistic & Prob. \\
\hline DAIL_Y_ASI_1_ & 1.000318 & $5.01 \mathrm{E}-06$ & 199490.4 & 0.0000 \\
\hline
\end{tabular}




\begin{tabular}{|c|c|c|c|c|}
\hline \multicolumn{5}{|c|}{ Dependent Variable: DAILY_ASI } \\
\hline \multicolumn{5}{|c|}{ Method: ML ARCH - Normal distribution (BFGS / Marquardt steps) } \\
\hline \multicolumn{5}{|c|}{ GARCH=C (3) + C (4)*RESID (-1)^2 + C (5)*GARCH (-1) } \\
\hline Variable & Coefficient & Std. Error & z-Statistic & Prob. \\
\hline \multirow[t]{2}{*}{$\mathrm{C}$} & -10.80190 & 0.260922 & -41.39895 & 0.0000 \\
\hline & Variance $\mathrm{Eq}$ & & & \\
\hline $\mathrm{C}$ & 4.663233 & 1.206180 & 3.866117 & 0.0001 \\
\hline $\operatorname{RESID}(-1)^{\wedge} 2$ & -0.069270 & 0.028074 & -2.467429 & 0.0136 \\
\hline GARCH (-1) & 0.516412 & 0.112157 & 4.604350 & 0.0000 \\
\hline R-squared & 0.959894 & Mean depe & & 32982.60 \\
\hline Adjusted R-squared & 0.959864 & S. D. deper & & 5642.280 \\
\hline S. E. of regression & 1130.375 & Akaike inf & & 4.476674 \\
\hline Sum squared resid & $1.70 \mathrm{E}+09$ & Schwarz cr & & 4.496161 \\
\hline Log likelihood & -2978.703 & Hannan-Q & & 4.483976 \\
\hline Durbin-Watson stat & 1.000113 & & & \\
\hline
\end{tabular}

The estimated standard GARCH $(1,1)$ Model presented in table 4 above shows that the conditional means $\mu$ and the lagged price parameter in the mean equation of the GARCH $(1,1)$ model $\alpha$ are significant.

Table 5. GARCH Model for Annual ASI.

\begin{tabular}{|c|c|c|c|c|}
\hline \multicolumn{5}{|c|}{ Dependent Variable: ANNUAL_ASI } \\
\hline \multicolumn{5}{|c|}{ Method: ML ARCH - Normal distribution (BFGS / Marquardt steps) } \\
\hline \multicolumn{5}{|c|}{ GARCH $=$ C (3) + C (4)*RESID (-1)^2 + C (5)*GARCH (-1) } \\
\hline Variable & Coefficient & Std. Error & z-Statistic & Prob. \\
\hline ANNUAL ASI 1 & 0.999972 & 0.002680 & 373.0871 & 0.0000 \\
\hline $\mathrm{C}$ & $\begin{array}{l}0.055972 \\
\text { Variance Eq }\end{array}$ & 56.39380 & 0.000993 & 0.9992 \\
\hline $\mathrm{C}$ & 85.79159 & 46.71339 & 1.836552 & 0.0663 \\
\hline $\operatorname{RESID}(-1)^{\wedge} 2$ & -0.069334 & 0.048208 & -1.438225 & 0.1504 \\
\hline GARCH (-1) & 0.488564 & 0.191065 & 2.557055 & 0.0106 \\
\hline R-squared & 0.999997 & Mean deper & & 15205.32 \\
\hline Adjusted R-squared & 0.999997 & S. D. depen & & 13992.35 \\
\hline S. E. of regression & 22.50055 & Akaike info & & 7.224405 \\
\hline Sum squared resid & 16200.79 & Schwarz cri & & 7.448870 \\
\hline Log likelihood & -117.8149 & Hannan-Qu & & 7.300954 \\
\hline Durbin-Watson stat & 1.000274 & & & \\
\hline
\end{tabular}

Authors' computation output using E-view 10.

The results of the GARCH models in Tables 4 and 5 show that the conditional means and the lagged price parameters in both of the mean equations are significantly different from zero. The error terms of the mean equations are not independently and identically distributed (iid) thereby suggesting inefficiency in the Nigerian Stock Market. Also the sum of the ARCH and GARCH parameters $\alpha+\beta$ is far away from $1(\alpha+\beta=0.41928)$ for the annual all share index and $(\alpha+\beta=0.447142)$ for daily all share index suggesting a low persistent of volatility clustering.

However, since the lagged values of the daily and annual ASI are positively and significantly different from zero and the error terms (by the rule of thumb, DW $<2$ ) is not independently distributed, the researchers concluded that the Nigerian stock market is inefficient.

\subsection{Autocorrelation and Partial Autocorrelation Tests}

For more authentications, the researchers proceeded to verifying with Autocorrelation test which is a special correlation test that examines the relationship between successive values of the same variable and not necessarily between two or more variables. The test is shown in table 6 below;

Table 6. Autocorrelation Test for Daily ASI.

\begin{tabular}{llllll}
\hline Autocorrelation & Partial Correlation & & AC & PAC & Q-Stat \\
\hline$* * * * * * *$ & $\mid * * * * * * *$ & 1 & 0.997 & 0.997 & 1327.3 \\
$\mid * * * * * * *$ & $*||$ & 2 & 0.993 & -0.148 & 2644.4 \\
$\mid * * * * * * *$ & || & 3 & 0.988 & -0.026 & 3950.5 \\
$\mid * * * * * * *$ & || & 4 & 0.983 & -0.013 & 5245.4 \\
$\mid * * * * * * *$ & || & 5 & 0.979 & -0.028 & 0.000 \\
$\mid * * * * * * *$ & || & 6 & 0.974 & 0.000 & 7800.0 \\
$\mid * * * * * *$ & || & 7 & 0.969 & 0.034 & 0.000 \\
$\mid * * * * * *$ & || & 8 & 0.965 & 0.024 & 0.00000 \\
\hline
\end{tabular}




\begin{tabular}{|c|c|c|c|c|c|c|}
\hline Autocorrelation & \multicolumn{2}{|c|}{ Partial Correlation } & $\mathbf{A C}$ & PAC & Q-Stat & Prob \\
\hline ******** & 11 & 9 & 0.960 & 0.018 & 11549. & 0.000 \\
\hline$* * * * * * *$ & | & 10 & 0.956 & -0.010 & 12779 . & 0.000 \\
\hline |******* & | & 11 & 0.952 & 0.015 & 13999. & 0.000 \\
\hline$* * * * * * *$ & | & 12 & 0.948 & 0.025 & 15210 . & 0.000 \\
\hline$* * * * * * *$ & | & 13 & 0.944 & -0.013 & 16412 . & 0.000 \\
\hline$* * * * * * *$ & | & 14 & 0.941 & 0.034 & 17606. & 0.000 \\
\hline |******* & | & 15 & 0.937 & -0.014 & 18791. & 0.000 \\
\hline |******* & | & 17 & 0.929 & -0.029 & 21134 & 0.000 \\
\hline |******* & | & 18 & 0.925 & 0.025 & 22293. & 0.000 \\
\hline$* * * * * * *$ & | & 19 & 0.921 & -0.024 & 23442 . & 0.000 \\
\hline |******* & | & 20 & 0.917 & -0.014 & 24582 . & 0.000 \\
\hline |******** & | & 21 & 0.913 & 0.005 & 25712 & 0.000 \\
\hline |******* & | & 22 & 0.908 & -0.045 & 26832 . & 0.000 \\
\hline |******** & | & 23 & 0.904 & -0.013 & 27942 . & 0.000 \\
\hline$|* * * * * *|$ & | & 26 & 0.890 & -0.003 & 31212. & 0.000 \\
\hline$|* * * * * *|$ & | & 27 & 0.886 & -0.034 & 32281. & 0.000 \\
\hline$|* * * * * *|$ & | & 28 & 0.881 & -0.049 & 33339. & 0.000 \\
\hline$|* * * * * *|$ & |1 & 29 & 0.875 & -0.023 & 34384. & 0.000 \\
\hline$|* * * * * *|$ & | & 30 & 0.870 & 0.023 & 35419. & 0.000 \\
\hline$|* * * * * *|$ & II & 31 & 0.865 & 0.014 & 36441. & 0.000 \\
\hline$|* * * * * *|$ & | & 32 & 0.860 & -0.011 & 37453. & 0.000 \\
\hline$|* * * * * *|$ & | & 33 & 0.855 & 0.003 & 38454 . & 0.000 \\
\hline$|* * * * * *|$ & | & 34 & 0.850 & 0.041 & 39444. & 0.000 \\
\hline$|* * * * * *|$ & | & 35 & 0.846 & 0.018 & 40425 . & 0.000 \\
\hline$|* * * * * *|$ & 11 & 36 & 0.842 & 0.009 & 41397. & 0.000 \\
\hline
\end{tabular}

Table 7. Autocorrelation Test for Annual ASI.

\begin{tabular}{|c|c|c|c|c|c|c|}
\hline Autocorrelation & Partial Correlation & & AC & PAC & Q-Stat & Prob \\
\hline$|* * * * * *|$ &.$|* * * * * *|$ & 1 & 0.849 & 0.849 & 26.713 & 0.000 \\
\hline||$* * * * * \mid$ &.$* 1$ & 2 & 0.689 & -0.110 & 44.895 & 0.000 \\
\hline||$^{* * * * *} \mid$ &.$|* *|$ & 3 & 0.637 & 0.293 & 60.921 & 0.000 \\
\hline$.||^{* * * *} \mid$ &.$*||$. & 4 & 0.568 & -0.141 & 74.068 & 0.000 \\
\hline$\cdot|* * * *|$ & $.\left.\right|^{*} . \mid$ & 5 & 0.494 & 0.084 & 84.365 & 0.000 \\
\hline.$|* * *|$ &.$||$. & 6 & 0.457 & 0.027 & 93.480 & 0.000 \\
\hline.$|* * *|$ & .1 .1 & 7 & 0.385 & -0.143 & 100.18 & 0.000 \\
\hline.$|* *|$ &. $\mid .1$ & 8 & 0.280 & -0.089 & 103.87 & 0.000 \\
\hline||$^{* *} \mid$ &.$||$. & 9 & 0.224 & 0.038 & 106.32 & 0.000 \\
\hline$.\left.\right|^{*} . \mid$ &.$||$. & 10 & 0.199 & 0.018 & 108.35 & 0.000 \\
\hline$.\left.\right|^{*} . \mid$ & $* *||$. & 11 & 0.087 & -0.309 & 108.74 & 0.000 \\
\hline.$||$. &.$* 1$ & 12 & -0.041 & -0.077 & 108.84 & 0.000 \\
\hline$*||$. &.$||$. & 13 & -0.126 & -0.139 & 109.76 & 0.000 \\
\hline.$* 1$ &.$||$. & 14 & -0.203 & -0.028 & 112.29 & 0.000 \\
\hline$* *||$. &.$||$. & 15 & -0.281 & -0.108 & 117.37 & 0.000 \\
\hline$* *||$. & .1 .1 & 16 & -0.323 & -0.017 & 124.44 & 0.000 \\
\hline
\end{tabular}

Authors' computation output using E-view 10.

Tables 6 and 7 above show the autocorrelation test for daily and annual data. Both revealed that the individual autocorrelation (AC) at different lags from 1-36 and the associated probability values suggest that successive autocorrelation of the prices are significant from 1-36 for daily ASI and 1-16 for annual ASI. This indicates that there is existence of volatility clustering in the price series and hence implies that the price series in both markets do not follow random walk.

\section{Concluding Remarks}

This study using the unit root test, GARCH model, autocorrelation and partial autocorrelation tests found that the Nigerian stock exchange is not weak form efficient within the period under study (1985-2019). The study on the daily and annual all share index indicate a significant relationship between the price series and their lagged values; thus, lending credence to the fact that price series do not follow a random walk in the Nigerian stock market. In other words, the findings affirmed that the Nigeria Stock Exchange is not efficient in weak form. This finding corroborates the findings of Emenike [22]; Gimba [31]; Afego [4]; Goudarzi [32] and Ogbulu [42] but contradicts the findings of Olowe [48], Keith and Graham [36], Okpara [44] and Ajao and Osayuwu [6]. 


\section{Recommendations}

In the light of this finding, the researchers suggest that the NSE should:

i. Palliate its regulations pertaining to transparency of information management rules such as market barriers and stringent listing requirement, publication of accounts, notices of annual general meeting, going to press without bureaucratic written approval of the exchange.

ii. Ensure timely disclosure and transparent dissemination of company specific information to the investors and other market operators.

iii. The capital trade points and local commodity exchanges incorporated in the SEC Act as a way of penetrating the rural populace should be made active and vibrant through adequate funding.

\section{References}

[1] Adebanjo, J. F., Awonusi, F. \& Eseyin, O. (2018). The weak form market efficiency and the Nigerian stock exchange. Afro Asian Journal of Social Science, 9 (4). 1-17.

[2] Adelegan. O. J. (2009), Price reactions to dividend announcements on the Nigerian stock market. AERC Research Paper 188. Nairobi.

[3] Afego, P. (2011). Stock price response to earnings announcements: evidence from Nigeria. Available at SSRN: http://ssrn.com/abstract=1768762. Retrieved 10/4/2020.

[4] Afego, P. (2012). Weak form efficiency of the nigerian stock market: An empirical analysis.. International Journal of Economics and Financial Issues. 2 (3), 340-347.

[5] Agwuegbo, S. O. N., Adewole, A. P. \& Maduegbuna, A. N. (2010). A random walk model for stock market prices. Journal of Mathematics and Statistics. 6 (3), 342-346.

[6] Ajao, G \& Osayuwu, R. (2012). Testing the weak form of efficient market hypothesis in Nigerian capital market. Accounting and Finance Research, 1 (1).

[7] Ayadi, S. \& Bouri, A. (2009). Intervening parties' behaviours and its impact on the financial market functioning. International Research Journal of Finance and Economics. $31,101-115$.

[8] Bachellier, L. (1900). Theorie de la Paris: Gauthier - Villars. Reprinted in English (Bones trans.) in Cootner PH edited 1964". The random character of stock market prices, MITpress.

[9] Bashir, T., David, P. \& Suzanne, F. (2009). An empirical investigation of the weak-form of the efficient market hypothesis for the Nigerian stock exchange. African Finance Journal. 11 (2), 1-27.

[10] Bhalla, V. K. (2011). Investment management: Security analysis and portfolio management. New Delhi: S. Chad and Company Ltd.

[11] Bodie, Z., Kane, A., Marcus, A. J. \& Mohanty, P. (2013). Investment ( $8^{\text {th }}$ editon). New Delhi: McGraw Hill Education.

[12] Brealey, R. A. \& Myers, S. C. (2003). Principles of corporate finance. New Delhi: McGraw Hill.

[13] Broyles, J. (2003). Financial management and real options. England: John Wiley \& Son Ltd.

[14] Chien-Chong, L., Jung-De, L, \& Chi-Chuan, L. (2010). Stock prices and the efficient market hypothesis: Evidence from a panel stationary test with structural breaks. Japan and the World Economy, (22) 1, 49-58.

[15] Cooray, V \& Wickramasighe, G. (2007). The efficiency of emerging stock markets: Empirical evidence from the South Asian region. Journal of Developing Areas. 41 (1), 171-183.

[16] Cuthbertson, K. \& Nitzsche, K. (2005). Investments: Spot and derivatives market. New York: JohnWilley and Sons Ltd.

[17] Dickinson, J. P. \& Muragu, K. (1994). Market efficiency in developing countries: A case study of the Nairobi stock exchange. Journal of Business Finance and Accounting, 21 (1), 133-150.

[18] Dimson, E. \& Mussavian, M. (1998). A brief of history of market efficiency. European Financial Management, 4 (1), 91-193.

[19] Downey, L. \& Scott, G. (2020). Efficient Market hypothesis. www.investopia.org. Retrieved on 09/04/2020.

[20] Edmans, A.(2009). Blockholder trading, market efficiency and managerial myopia. The Journal of Finance, 64 (6), 2481 - 2513.

[21] Efobi. U. R. (2010). The efficient market hypothesis: Realities from the Nigerian stock market. Global Journal of Finance and Management, 2 (2), 321-331.

[22] Emenike, K. O. (2008). Empirical test for weak form efficient market hypothesis of the Nigerian stock exchange. Social Science Research Network (SSRN). Working Paper Series.

[23] Ezirim, B. C. (2005). Finance dynamics: Principles, techniques and approaches. Portharcourt: Markowitz Centre for Research and Development.

[24] Fama, E. (1965). The behaviour of stock market prices. Journal of Business, 38, January edition, 34-49.

[25] Fama, E. F. (1976). Reply to efficient capital markets: Comments. Journal of Finance, 31 (1), 143-145

[26] Fama, E. F. (1970). Efficient capital markets: A review of theory and empirical work. Journal of Finance, 25 (1), 83417.

[27] Fisher, D. E. \& Jordan, R. J. (2005). Security analysis and portfolio management. Delhi: Pearson Education.

[28] Gagan. D. S \& Mahendru. M. (2009). Efficiency hypothesis of the stock markets: A case of Indian securities. International Journal of Business and Management. Available at SSRN: http://ssrn.com/abstract $=1827522$. Retrieved 01/3/2020.

[29] Gao, P. (2008). Keynesian beauty contest, accounting disclosure and market efficiency. Journal of Accounting Research, 46 (4), 785-807.

[30] George, E. O. \& Oseni, J. E. (2012). The influence of information asymmetry on equity pricing: A theoretical perspective. American Journal of Scientific Research, 65, 4250. 
[31] Gimba, V. K. (2012). Testing the weak form efficiency market hypothesis: Evidence from Nigeria stock market. $C B N$ Journal of Applied Statistics, 3 (1), 117-136.

[32] Goudarzi, H. (2013). Volatility mean reversion and stock market efficiency. Asian Economic and Financial Review, 3 (13), 1681-1692.

[33] Heman, S. C. (2001). Security management and the validity of portfolio market theories, An MBA. Project submitted to the Department of Business Administration, University of Benin, Nigeria.

[34] Ibenta, S. N. (2005). Investment analysis and financial management strategy. Enugu: Institute of Development Studies.

[35] Jones, S. L. \& Netter, J. M. (2008). Efficient capital markets. The concise encyclopedia of economics. Library of economics and liberty. Http://www.econlib.org/library/Enc/EfficientCapitalMarkets.h tml. Retrieved 20/2/2020.

[36] Keith. J \& Graham. S (2005). The changing efficiency of African stock markets. South African Journal of Economics 73, 1.

[37] Kendall, M. G. (1953). The analysis of economic time series, Prices. Journal of the Royal Statistical Society, 96, 11-25.

[38] Liu, C. and He, J. (1991). A variance - ratio test of random walks in foreign exchange rates. Journal of finance, 46 (2), 773-785.

[39] Malkiel (1973). A Random walk down wall street: The TimeTested strategy for successful investing. New York: W. W Norton and Co.

[40] Manasseh, O. C, Asogwa, F. O \& Agu, D. O (2012). The causality effect of stock market development, financial sector reforms and economic growth in Nigeria; The Applicationof Vector Autoregressive (VAR) and Vector Error Correction Model (VECM). A Paper presented at the Global Development Finance Conference. Crystal Towers, Century City, Cape Town, South Africa.

[41] Nasir, M. A., Khan, K. \& Rossi M. (2016). The calendar anomalies on performance and volatility of stock market: The effects of Ramadan on Karachi Stock exchange. https://www.researchgate.net/publication/322984494. Accessed, Apr 132020.

[42] Ogbulu, O. M. (2016). Weak-form market efficiency, estimation interval and the Nigerian Stock Exchange: Empirical evidence. International Journal of Economic and Business, 5 (1), 84-116.

[43] Ogundina, J. A \& Omah, I. (2013). Test of capital market efficiency theory in the Nigerian capital market. Research Journal of Finance and Accounting. 4 (1).

[44] Okpara, G. C. (2010a). Stock market prices and the random walk hypothesis: Further evidence from Nigeria. Journal of Economics and International Finance, 2 (3), 49-57.

[45] Okpara, G. C. (2010b). Analysis of weak form efficiency on the Nigerian stock Market: Further evidence from GARCH model. The International Journal of Applied Economics and Finance, 4 (2), 62-66.

[46] Okpara, G. C. (2012). Fundamentals of corporate financial management. Uyo: Donil Prints Ltd.
[47] Okpare, G. C. (2011). Random walk. Semi-strong hypothesis and market behavior: A test of weak and semi-strong form efficiency in the Nigerian stock market. USA: LAP LAMBERT Publishing.

[48] Olowe, A. R. (1999). Weak form efficiency of the Nigeria stock market: Further evidence. African Development Review. 11,54 .

[49] Oludoyi, S. B. (1998). Capital market efficiency and the effects of earning announcements on share prices in Nigeria. $P h D$. Thesis, University of Ibadan, unpublished.

[50] Osaze, B. E. (2000). Nigerian Capital Market in the African and Global Financial System, Benin City: Bofic Consulting Group Limited.

[51] Osinubi, T. S. (2000). Does stock market promote economic growth in Nigeria? http://sta.uwi.edu/conferences/financeconference. Rtrieved $3 / 2 / 2020$.

[52] Otaniyi, O. \& Makina, D. (2010). Price behaviour of new share listings in Nigeria. International Business \& Economics Research Journal. 9, 4.

[53] Peterson, K (1905) The problem of Random Walk. Nature; 72: 294-34.

[54] Rayleagh L (1905). A Random walks. Nature, 73: 174.

[55] Reily, F. K. (1989). Investment analysis and portfolio management, Hinsdale, Illinois: Dryden Press.

[56] Ross, S. A., Westerfield, R. W., Jaffe, J. \& Jordan, B. D. (2009). Modern financial management ( $8^{\text {th }}$ edition). New Delhi: McGraw Hill.

[57] Rossi, M. (2016). The capital asset pricing model: A critical literature review. Global Business and Economics Review, 18 (5), 604-617.

[58] Rossi, M. \& Guardi, A. (2018). Efficient market hypothesis and stock market anomalities: Empirical evidence in four European countries. The Journal of Applied Business Research, 34 (1), 183-192.

[59] Sabur, M \& Vitali, F. (2011). Stock market efficiency in Africa, Evidence from random walk hypothesis. $w w w$. Googlescholar.com. Retrieved 4/3/2020.

[60] Samuels, J. M \& R. Wilkes (1981). Management of Company Finance, Lagos: Thomas Nelson.

[61] Segal, T. (2019). Market timing. www.investopia.org. Retrieved 0n 09/04/2020.

[62] Sergeant, T. J. \& Wallace, N. (1975). Rational expectations, the optimal monetary instrument, and the optimal money supply rule. Journal of Political Economy, 83, 241-54.

[63] Sharpe, W. F., Alexander, G. J. \& Bailey, J. V. (1999). Investments. (6th Edition). Upper Saddle River: Prentice-Hall, Inc.

[64] Udoka, C. O. (2012). Weak-form market efficiency: Dynamic effects of information on the Nigerian stock market. Interdisciplinary journal of contemporary research in business, 4, 7 .

[65] Wong K. \& Kwong K, (1984). The behaviour of Hong Kong stock prices. Applied Economics. 16, 905-917. 